\title{
Associations of Genetic Variants of Methylenetetrahydrofolate Reductase and Serum Folate Levels with Metabolic Parameters in Patients with Schizophrenia
}

\author{
Chun-Hsin Chen ${ }^{1,2, *,+}$, Po-Yu Chen ${ }^{3,4}$, Cynthia Yi-An Chen ${ }^{2}$, Chih-Chiang Chiu ${ }^{1,3}$, Mong-Liang Lu 1,2, \\ Ming-Chyi Huang ${ }^{1,3}$, Yen-Kuang Lin ${ }^{5}\left(\right.$ ) and Yi-Hua Chen ${ }^{6, *,+}$
}

1 Department of Psychiatry, School of Medicine, College of Medicine, Taipei Medical University, Taipei 110, Taiwan; Eric.ccchiu@gmail.com (C.-C.C.); mongliang@hotmail.com (M.-L.L.); mingchyihuang@gmail.com (M.-C.H.)

2 Department of Psychiatry, Wan Fang Hospital, Taipei Medical University, Taipei 116, Taiwan; cyn.placido@gmail.com

3 Department of Psychiatry, Taipei City Psychiatric Center, Taipei City Hospital, Taipei 110, Taiwan; boyu.chen@gmail.com

4 Graduate Institute of Medical Science, School of Medicine, Taipei Medical University, Taipei 110, Taiwan

5 Biostatistics Center, Taipei Medical University, Taipei 110, Taiwan; robbinlin@tmu.edu.tw

6 School of Public Health, College of Public Health, Taipei Medical University, Taipei 110, Taiwan

* Correspondence: chunhsin57@gmail.com (C.-H.C.); yichen@tmu.edu.tw (Y.-H.C.);

Citation: Chen, C.-H.; Chen, P.-Y.; Chen, C.Y.-A.; Chiu, C.-C.; Lu, M.-L.; Huang, M.-C.; Lin, Y.-K.; Chen, Y.-H. Associations of Genetic Variants of Methylenetetrahydrofolate Reductase and Serum Folate Levels with Metabolic Parameters in Patients with Schizophrenia. Int. J. Environ. Res Public Health 2021, 18, 11333. https://doi.org/10.3390/ ijerph182111333

Academic Editor: Paul B. Tchounwou

Received: 26 September 2021

Accepted: 26 October 2021

Published: 28 October 2021

Publisher's Note: MDPI stays neutral with regard to jurisdictional claims in published maps and institutional affiliations.

Copyright: (C) 2021 by the authors. Licensee MDPI, Basel, Switzerland. This article is an open access article distributed under the terms and conditions of the Creative Commons Attribution (CC BY) license (https:// creativecommons.org/licenses/by/ $4.0 /)$
Tel.: +886-2-2930-7930 (ext. 53961) (C.-H.C.); Fax: +886-2-2933-5221 (C.-H.C.)

+ Equal contributions to the work and share the correspondence.

Abstract: The one-carbon metabolism pathway is a suitable candidate for studying the genetic and epigenetic factors contributing to metabolic abnormalities in patients with schizophrenia. We recruited 232 patients with schizophrenia and analyzed their serum folate, vitamin B12, and homocysteine levels and metabolic parameters to investigate the associations of genetic variants of methylenetetrahydrofolate reductase (MTHFR) and folate levels with metabolic parameters. MTHFR C677T and MTHFR A1298C were genotyped. Results showed that MTHFR 677T allele carriers had lower levels of total cholesterol and low-density lipoprotein cholesterol than those with the 677CC genotype. Metabolic parameters did not differ between MTHFR 1298C and 1298AA carriers. Patients with a low folate level had a lower high-density lipoprotein cholesterol level than those with a normal folate level, but the effect disappeared after adjustment for age, sex, and types of antipsychotics used. We found significant interactions between MTHFR A1298C and the folate level status (low vs. normal) in terms of body mass index and waist circumference. In conclusion, genetic variants in one-carbon metabolism might play a role in antipsychotic-induced metabolic abnormalities. Prospective studies on drug-naïve, first-episode patients with schizophrenia are warranted to identify key regions of DNA methylation changes accounting for antipsychotic-induced metabolic abnormalities.

Keywords: folate; methylenetetrahydrofolate reductase; metabolic parameters; one-carbon metabolism; schizophrenia

\section{Introduction}

Metabolic abnormalities are a serious concern in patients with schizophrenia. Clozapine and olanzapine are antipsychotics that have the highest propensity to induce body weight gain and metabolic abnormalities [1]; however, not all patients treated with clozapine or olanzapine experience metabolic adverse effects [2]. Furthermore, some evidence has shown that increased visceral fat and impaired fasting glucose tolerance are already present in drug-naïve patients with schizophrenia [3,4]. These observations suggest that, in addition to antipsychotic treatment, genetic or epigenetic factors may contribute to metabolic abnormalities in patients with schizophrenia $[5,6]$. 
Enzyme abnormalities in one-carbon metabolism have been found in the blood cells of patients with schizophrenia $[7,8]$. In the one-carbon metabolism pathway, 5,10methelenetetrahydrofolate reductase (MTHFR), a regulatory enzyme, converts 5,10methylene tetrahydrofolate (5,10-MTHF) to 5-methyltetrahydrofolate (5-MTHF), which is a key methyl donor for homocysteine remethylation to methionine. MTHFR C677T and MTHFR A1298C are two common functional genetic variants of MTHFR related to MTHFR enzyme activity $[9,10]$. For example, each copy of MTHFR C677T T allele reduces MTHFR activity by approximately $35 \%$ [9]. The low activity of MTHFR impedes the conversion of homocysteine to methionine that is used to methylate DNA. In addition, decreased availability to folate may induce homocysteine accumulation because of the inability of homocysteine to be metabolized to methionine. Homocysteine elevation and methionine reduction following low activity of MTHFR and low folate availability result in DNA hypomethylation $[11,12]$, which has been shown to be associated with hyperglycemia and low high-density lipoprotein cholesterol (HDL-C) levels [13]. A meta-analysis showed that MTHFR 677T carriers, particularly those with low folate levels, are at increased risk for coronary heart disease [14]. Whether the genetic effect specifically related to low folate level holds true for schizophrenia is unknown.

MTHFR is one of the susceptibility genes in schizophrenia and type 2 diabetes mellitus [15]. In patients with schizophrenia, the associations between genetic variants of MTHFR and metabolic parameters are inconsistent in the literature. Ellingrod et al. found that MTHFR 677T carriers were more vulnerable to metabolic syndrome than those with MTHFR 677CC in a sample mainly comprising Caucasian patients with schizophrenia [16]. Contrarily, Roffeei et al. found that the MTHFR 677T allele was protective against metabolic syndrome in Malaysian and Chinese patients with schizophrenia [17]. Furthermore, the genetic heterogeneity of MTHFR among different regions of the world has been demonstrated [18], and the effects of genetic variants of MTHFR on homocysteine levels differ among various regions [19]. These findings indicate that ethnic factors should be considered when estimating the associations between genetic variants of MTHFR and metabolic syndrome.

Given the evidence that MTHFR genotypes potentially affect the metabolic profiles in patients with schizophrenia treated with antipsychotics, and that the effects may be related to low folate levels and may differ among different ethnicities, we explored the associations of MTHFR genetic variants and serum folate level with metabolic parameters in patients with schizophrenia treated with antipsychotics in the Han Chinese population in Taiwan. Because low function of MTHFR and low folate availability result in DNA hypomethylation, which might contribute to metabolic abnormalities [13], we hypothesized that patients with the minor allele of MTHFR (i.e., MTHFR 677T or MTHFR 1298C) and those with a low folate level may have worse metabolic parameters.

\section{Material and Methods}

\subsection{Participants and Settings}

The study was a part of a screening phase of a randomized trial investigating folate supplementation in patients with schizophrenia (ClinicalTrial.gov identifier: NCT02916121). The trial was conducted in outpatient clinics of Taipei Medical University-Wan Fang Hospital and Taipei City Psychiatric Center from October 2014 to December 2017, in accordance with the Declaration of Helsinki. The protocol was approved by the Research Ethical Committees of both institutes. The inclusion criteria were as follows: (1) age between 20 and 65 years; (2) fulfillment of the DSM-IV-TR criteria for schizophrenia or schizoaffective disorder, as verified by two board-certified psychiatrists; (3) treatment with an antipsychotic agent for at least 6 months or at a stable dose for at least 3 months. The exclusion criteria were as follows: (1) medically unstable status; (2) current vitamin supplementation; (3) current pregnancy or lactation; (4) presence of substance use disorder (including abuse and dependence) based on a clinical interview and urine tests during the preceding year. After initial assessments, a comprehensive description of the study was provided to the eligible participants, and written informed consent for participation 
was obtained before including them in the study. If patients could not understand the study protocol owing to impaired cognition, we explained the protocol to their caregivers and obtained informed consent under their supervision. The participants could decide to withdraw their informed consents anytime during the study period. Data including age, sex, diagnosis, and age at onset of schizophrenia of the recruited patients were collected from clinical interviews and medical records.

\subsection{Clinical Assessment}

Trained research assistants, who had completed at least $6 \mathrm{~h}$ of training for conducting human research or clinical trials each year before recruiting patients, or psychiatrists conducted all the assessments, including height, body weight, sitting blood pressure (BP), and waist circumference.

\subsection{Laboratory Assays}

We withdrew fasting venous blood between 8:00 and 10:00 a.m. Baseline biochemical assays were performed in advance to ensure no abnormality in general biochemical screening. Serum levels of folate, vitamin B12, and homocysteine and metabolic parameters, including fasting plasma glucose (FPG), triglyceride, total cholesterol, low-density lipoprotein cholesterol (LDL-C), and HDL-C, were measured using an automated system. We used a serum folate level of $6 \mathrm{ng} / \mathrm{mL}$ as the cutoff to categorize patients into the low folate level $(\leq 6 \mathrm{ng} / \mathrm{mL})$ and normal folate level $(>6 \mathrm{ng} / \mathrm{mL})$ [20]. Metabolic syndrome was defined based on the International Diabetes Federation Task Force Criteria; three or more of the following five criteria were required: (1) waist circumference greater than $90 \mathrm{~cm}$ in men and greater than $80 \mathrm{~cm}$ in women; (2) fasting serum triglyceride levels of $150 \mathrm{mg} / \mathrm{dL}$ or above; (3) fasting serum HDL-C levels less than $40 \mathrm{mg} / \mathrm{dL}$ in men or less than $50 \mathrm{mg} / \mathrm{dL}$ in women; (4) systolic BP higher or equal to $130 \mathrm{~mm} \mathrm{Hg}$, diastolic BP higher or equal to $85 \mathrm{~mm} \mathrm{Hg}$, or current treatment with antihypertensive medication; (5) an FPG level of $100 \mathrm{mg} / \mathrm{dL}$ or above, or current treatment with antihyperglycemic medication [21].

\subsection{DNA Assays}

Genomic DNA was isolated from blood using standard protocols and was stored in a $-80^{\circ} \mathrm{C}$ refrigerator until genetic assays were conducted. Genetic variants of MTHFR C677T (rs1801133) and MTHFR A1298C (rs1801131) were genotyped using the ABI StepONE Plus ${ }^{\text {TM }}$ Software v2.1 genotyping assay (Thermo Fisher Scientific, Waltham, MA, USA).

\subsection{Statistical Analysis}

We used descriptive statistics to present demographic characteristics and laboratory data, including metabolic parameters, in recruited patients. Independent $t$-test and chisquare test were used to evaluate the differences in continuous variables and categorical variables between groups, respectively. General linear model was used to control for potential confounders to evaluate the main effects of MTHFR polymorphisms and serum folate level status, as well as their interaction effects, on metabolic parameters. A $p$-value of $<0.05$ indicated statistical significance.

\section{Results}

A total of 232 participants were enrolled in our study. Table 1 presents the demographic and clinical characteristics, genetic variants of MTHFR C677T and MTHFR A1298C, and laboratory data of the participants. Clozapine (35.8\%) and olanzapine $(13.4 \%)$ accounted for the most commonly used antipsychotics. The distributions of genetic variants of MTHFR C677T and MTHFR A1298C did not violate the Hardy-Weinberger equilibrium. 
Table 1. Demographic characteristics, MTHFR genotypes, and metabolic parameters of patients with schizophrenia $(n=232)$.

\begin{tabular}{|c|c|}
\hline Variables & \\
\hline Age $^{\text {a }}$ (years), mean $\pm S D$ & $44.3 \pm 10.7$ \\
\hline Sex, male/female, $n(\%)$ & $115 / 117(49.6 / 50.4)$ \\
\hline Onset age ${ }^{b}$ (years), mean \pm SD & $24.1 \pm 8.9$ \\
\hline Duration of illness ${ }^{\mathrm{c}}$ (years), mean $\pm \mathrm{SD}$ & $19.8 \pm 10.5$ \\
\hline \multicolumn{2}{|l|}{ Antipsychotic use, $n(\%)$} \\
\hline Clozapine & $83(35.8)$ \\
\hline Olanzapine & $31(13.4)$ \\
\hline Risperidone & $25(10.8)$ \\
\hline Haloperidol & $22(9.5)$ \\
\hline Aripiprazole & $14(6.0)$ \\
\hline Others & $57(24.5)$ \\
\hline \multicolumn{2}{|l|}{ MTHFR C677T (rs1801133) } \\
\hline $\mathrm{C} / \mathrm{C}, n(\%)$ & $116(50.0)$ \\
\hline $\mathrm{C} / \mathrm{T}, n(\%)$ & $97(41.8)$ \\
\hline $\mathrm{T} / \mathrm{T}, n(\%)$ & $19(8.2)$ \\
\hline \multicolumn{2}{|l|}{ MTHFR A1298C (rs1801131) } \\
\hline $\mathrm{A} / \mathrm{A}, n(\%)$ & $152(65.5)$ \\
\hline $\mathrm{A} / \mathrm{C}, n(\%)$ & $66(28.4)$ \\
\hline $\mathrm{C} / \mathrm{C}, n(\%)$ & $14(6.0)$ \\
\hline $\mathrm{BMI}^{\mathrm{d}}\left(\mathrm{kg} / \mathrm{m}^{2}\right)$, mean $\pm \mathrm{SD}$ & $26.7 \pm 5.1$ \\
\hline Antipsychotic use, olanzapine/clozapine, $n(\%)$ & $116(50)$ \\
\hline $\mathrm{WC}^{\mathrm{d}}(\mathrm{cm})$, mean $\pm \mathrm{SD}$ & $91.0 \pm 12.5$ \\
\hline $\mathrm{SBP}^{\mathrm{d}}(\mathrm{mmHg})$, mean $\pm \mathrm{SD}$ & $124.2 \pm 18.3$ \\
\hline $\mathrm{DBP}^{\mathrm{d}}(\mathrm{mmHg})$, mean $\pm \mathrm{SD}$ & $77.3 \pm 12.0$ \\
\hline $\mathrm{TG}(\mathrm{mg} / \mathrm{dL})$, mean $\pm \mathrm{SD}$ & $148.1 \pm 87.0$ \\
\hline Total cholesterol (mg/dL), mean $\pm \mathrm{SD}$ & $189.6 \pm 38.8$ \\
\hline HDL-C (mg/dL), mean \pm SD & $51.3 \pm 16.7$ \\
\hline $\mathrm{LDL}-\mathrm{C}(\mathrm{mg} / \mathrm{dL})$, mean $\pm \mathrm{SD}$ & $119.6 \pm 35.6$ \\
\hline $\mathrm{FPG}(\mathrm{mg} / \mathrm{dL})$, mean $\pm \mathrm{SD}$ & $108.5 \pm 39.3$ \\
\hline Folate $(\mathrm{ng} / \mathrm{mL})$, mean $\pm \mathrm{SD}$ & $8.6 \pm 3.9$ \\
\hline Homocysteine $(\mu \mathrm{mol} / \mathrm{mL})$, mean $\pm \mathrm{SD}$ & $16.4 \pm 14.3$ \\
\hline Vitamin B12 $(\mathrm{pg} / \mathrm{mL})$, mean $\pm \mathrm{SD}$ & $432.1 \pm 266.6$ \\
\hline
\end{tabular}

a Two missing data; ${ }^{\mathrm{b}} 19$ missing data; ${ }^{\mathrm{c}} 20$ missing data; ${ }^{\mathrm{d}}$ six missing data in these variables. Abbreviations: BMI, body mass index; DBP, diastolic blood pressure; FPG, fasting plasma glucose; HDL-C, high-density lipoprotein cholesterol; LDL, low-density lipoprotein cholesterol; MTHFR, methylenetetrahydrofolate reductase; SBP, systolic blood pressure; TG, triglyceride; WC, waist circumference.

Table 2 presents the demographic characteristics and laboratory data of patients with different genotypes of MTHFR C677T and MTHFR A1298C. Patients who were MTHFR 677T carriers (CT/TT) had significantly lower levels of total cholesterol, LDL-C, folate, and vitamin B12 and a higher level of homocysteine than those with the CC genotype. Regarding MTHFR A1298C, the metabolic parameters were comparable between patients with the 1298C genotype and those with the 1298AA genotype. 
Table 2. Demographic characteristics and metabolic parameters between different genotypes of MTHFR.

\begin{tabular}{|c|c|c|c|c|c|c|}
\hline & \multicolumn{2}{|c|}{ MTHFR C677T } & \multicolumn{4}{|c|}{ MTHFR A1298C } \\
\hline & $\mathrm{C} / \mathrm{C}$ & $\mathrm{C} / \mathrm{T}+\mathrm{T} / \mathrm{T}$ & $p$ & A/A & $\mathrm{A} / \mathrm{C}+\mathrm{C} / \mathrm{C}$ & $p$ \\
\hline & $n=116$ & $n=116$ & & $n=152$ & $n=80$ & \\
\hline $\begin{array}{l}\text { Age }^{\text {a }} \text { (years) } \\
\text { mean } \pm \text { SD }\end{array}$ & $44.3 \pm 10.0$ & $44.4 \pm 11.4$ & 0.92 & $44.5 \pm 10.5$ & $43.9 \pm 11.0$ & 0.61 \\
\hline $\begin{array}{l}\text { Sex, male } / \text { female, } n \\
(\%)\end{array}$ & $\begin{array}{c}54 / 62 \\
(46.6 / 53.4)\end{array}$ & $\begin{array}{c}61 / 55 \\
(52.6 / 47.4)\end{array}$ & 0.36 & $\begin{array}{c}74 / 78 \\
(48.7 / 51.3)\end{array}$ & $\begin{array}{c}41 / 39 \\
(51.2 / 48.8)\end{array}$ & 0.71 \\
\hline $\begin{array}{l}\text { Onset age }{ }^{\mathrm{b}} \text { (years), } \\
\text { mean } \pm \mathrm{SD}\end{array}$ & $23.9 \pm 8.7$ & $24.3 \pm 9.1$ & 0.84 & $24.1 \pm 8.8$ & $24.1 \pm 9.0$ & 0.98 \\
\hline $\begin{array}{c}\text { Duration of } \\
\text { illness }{ }^{c} \text {, years, } \\
\text { mean } \pm \text { SD }\end{array}$ & $20.3 \pm 9.9$ & $19.3 \pm 11.1$ & 0.51 & $19.9 \pm 10.6$ & $19.7 \pm 10.4$ & 0.93 \\
\hline $\begin{array}{c}\text { Olanzapine/clozapine, } \\
n(\%)\end{array}$ & 59 (50.9) & $55(47.4)$ & 0.60 & 78 (51.3) & $36(45.0)$ & 0.36 \\
\hline $\begin{array}{l}\mathrm{BMI}{ }^{\mathrm{d}}\left(\mathrm{kg} / \mathrm{m}^{2}\right) \\
\text { mean } \pm \mathrm{SD}\end{array}$ & $27.0 \pm 5.1$ & $26.3 \pm 5.2$ & 0.35 & $26.4 \pm 4.9$ & $27.1 \pm 5.7$ & 0.35 \\
\hline $\begin{array}{l}\mathrm{WC}^{\mathrm{d}}(\mathrm{cm}) \\
\text { mean } \pm \mathrm{SD}\end{array}$ & $91.3 \pm 13.3$ & $90.7 \pm 11.7$ & 0.70 & $90.6 \pm 11.7$ & $91.8 \pm 13.9$ & 0.48 \\
\hline $\begin{array}{l}\mathrm{SBP}^{\mathrm{d}}(\mathrm{mmHg}) \\
\text { mean } \pm \mathrm{SD}\end{array}$ & $123.6 \pm 18.3$ & $124.8 \pm 18.5$ & 0.62 & $124.8 \pm 18.4$ & $123.1 \pm 18.3$ & 0.50 \\
\hline $\begin{array}{l}\mathrm{DBP}^{\mathrm{d}}(\mathrm{mmHg}) \\
\text { mean } \pm \mathrm{SD}\end{array}$ & $77.4 \pm 11.8$ & $77.2 \pm 12.2$ & 0.92 & $77.1 \pm 12.1$ & $77.6 \pm 11.9$ & 0.79 \\
\hline $\begin{array}{l}\mathrm{TG}(\mathrm{mg} / \mathrm{dL}) \\
\text { mean } \pm \mathrm{SD}\end{array}$ & $149.0 \pm 85.7$ & $147.1 \pm 88.6$ & 0.87 & $150.7 \pm 90.0$ & $143.2 \pm 81.3$ & 0.53 \\
\hline $\begin{array}{c}\text { Total cholesterol } \\
(\mathrm{mg} / \mathrm{dL}), \text { mean } \pm \mathrm{SD}\end{array}$ & $194.8 \pm 40.8$ & $184.4 \pm 36.1$ & 0.04 & $188.6 \pm 35.9$ & $191.5 \pm 43.9$ & 0.60 \\
\hline $\begin{array}{l}\mathrm{HDL}-\mathrm{C}(\mathrm{mg} / \mathrm{dL}) \\
\text { mean } \pm \mathrm{SD}\end{array}$ & $50.7 \pm 16.2$ & $51.9 \pm 17.2$ & 0.58 & $51.5 \pm 15.7$ & $50.9 \pm 18.6$ & 0.79 \\
\hline $\begin{array}{l}\text { LDL-C }(\mathrm{mg} / \mathrm{dL}) \\
\text { mean } \pm \mathrm{SD}\end{array}$ & $125.2 \pm 38.4$ & $114.1 \pm 31.9$ & 0.02 & $118.0 \pm 34.0$ & $122.8 \pm 38.6$ & 0.33 \\
\hline $\begin{array}{l}\text { FPG }(\mathrm{mg} / \mathrm{dL}) \\
\text { mean } \pm \mathrm{SD}\end{array}$ & $109.0 \pm 42.4$ & $108.0 \pm 36.1$ & 0.85 & $110.3 \pm 44.9$ & $105.0 \pm 25.5$ & 0.32 \\
\hline $\begin{array}{l}\text { Folate }(\mathrm{ng} / \mathrm{mL}) \\
\text { mean } \pm \mathrm{SD}\end{array}$ & $9.5 \pm 3.9$ & $7.7 \pm 3.7$ & $<0.001$ & $8.5 \pm 3.9$ & $8.8 \pm 3.9$ & 0.49 \\
\hline Low folate, $n(\%)$ & $19(16.4)$ & 46 (39.7) & $<0.001$ & $42(27.6)$ & $23(28.7)$ & 0.86 \\
\hline $\begin{array}{l}\text { Homocysteine } \\
(\mu \mathrm{mol} / \mathrm{mL}) \\
\text { mean } \pm \mathrm{SD}\end{array}$ & $13.3 \pm 5.1$ & $19.4 \pm 19.0$ & 0.001 & $17.8 \pm 17.0$ & $13.6 \pm 5.4$ & 0.03 \\
\hline $\begin{array}{l}\text { Vitamin B12 }(\mathrm{pg} / \mathrm{mL}) \\
\text { mean } \pm \mathrm{SD}\end{array}$ & $480.5 \pm 307.5$ & $383.4 \pm 207.9$ & 0.005 & $422.8 \pm 265.3$ & $449.8 \pm 269.8$ & 0.47 \\
\hline
\end{tabular}

$\overline{{ }^{a}}$ Two missing data; ${ }^{\mathrm{b}} 19$ missing data; ${ }^{\mathrm{c}} 20$ missing data; ${ }^{\mathrm{d}}$ six missing data in these variables Abbreviations: BMI body mass index; DBP, diastolic blood pressure; FPG, fasting plasma glucose; HDL-C, high-density lipoprotein cholesterol; LDL, low-density lipoprotein cholesterol; MTHFR, methylenetetrahydrofolate reductase; SBP, systolic blood pressure; TG, triglyceride; WC, waist circumference.

When we categorized our patients on the basis of a cutoff level of $6 \mathrm{ng} / \mathrm{mL}$, mean age was younger and there were fewer female patients with low folate levels than those with normal folate levels (shown in Table 3). The percentage of patients using clozapine or olanzapine was higher in patients with low serum folate levels than those with normal folate levels. In addition, patients with a low folate level had significantly lower levels of serum HDL-C and vitamin B12 and higher levels of homocysteine compared with those with a normal folate level. When we further adjusted the effect of age, sex, and type of antipsychotics used, the difference in HDL-C level between the two groups disap- 
peared, whereas the significant difference in the levels of vitamin B12 and homocysteine remained unchanged.

Table 3. Demographics, clinical characteristics, and metabolic parameters of patients with low folate level and those with normal folate level.

\begin{tabular}{|c|c|c|c|}
\hline & $\begin{array}{l}\text { Patients with Low } \\
\text { Folate Level }(\leq 6 \mathrm{ng} / \mathrm{mL})\end{array}$ & $\begin{array}{l}\text { Patients with Normal } \\
\text { Folate Level }(>6 \mathrm{ng} / \mathrm{mL})\end{array}$ & $p$ \\
\hline & $n=65$ & $n=167$ & \\
\hline Age $^{\text {a }}$ (years), mean \pm SD & $41.8 \pm 11.1$ & $45.3 \pm 10.4$ & 0.03 \\
\hline Sex, male $/$ female, $n(\%)$ & $40 / 25(61.5 / 38.5)$ & $75 / 92(44.9 / 55.1)$ & 0.02 \\
\hline $\begin{array}{l}\text { Onset age }{ }^{b} \text { (years), } \\
\text { mean } \pm S D\end{array}$ & $23.5 \pm 8.5$ & $24.3 \pm 9.0$ & 0.53 \\
\hline $\begin{array}{l}\text { Duration of illness }{ }^{c} \\
\text { (years), mean } \pm S D\end{array}$ & $17.9 \pm 10.1$ & $20.6 \pm 10.6$ & 0.09 \\
\hline $\begin{array}{c}\text { Olanzapine/clozapine, } \\
n(\%)\end{array}$ & $90(53.9)$ & $24(36.9)$ & 0.02 \\
\hline $\begin{array}{c}\mathrm{BMI}^{\mathrm{d}}\left(\mathrm{kg} / \mathrm{m}^{2}\right) \\
\text { mean } \pm \mathrm{SD}\end{array}$ & $27.7 \pm 5.7$ & $26.3 \pm 4.9$ & 0.054 \\
\hline $\mathrm{WC}^{\mathrm{d}}(\mathrm{cm})$, mean $\pm \mathrm{SD}$ & $92.9 \pm 11.9$ & $90.2 \pm 12.7$ & 0.15 \\
\hline $\begin{array}{l}\mathrm{SBP}^{\mathrm{d}}(\mathrm{mmHg}) \\
\text { mean } \pm \mathrm{SD}\end{array}$ & $123.7 \pm 19.9$ & $124.4 \pm 17.8$ & 0.80 \\
\hline $\begin{array}{l}\mathrm{DBP}^{\mathrm{d}}(\mathrm{mmHg}) \\
\text { mean } \pm \mathrm{SD}\end{array}$ & $78.0 \pm 12.4$ & $77.0 \pm 11.8$ & 0.57 \\
\hline $\mathrm{TG}(\mathrm{mg} / \mathrm{dL})$, mean $\pm \mathrm{SD}$ & $149.6 \pm 77.8$ & $147.5 \pm 90.5$ & 0.87 \\
\hline $\begin{array}{c}\text { Total cholesterol } \\
(\mathrm{mg} / \mathrm{dL}), \text { mean } \pm \mathrm{SD}\end{array}$ & $188.2 \pm 41.3$ & $190.1 \pm 37.9$ & 0.74 \\
\hline $\begin{array}{l}\mathrm{HDL}-\mathrm{C}(\mathrm{mg} / \mathrm{dL}) \\
\text { mean } \pm \mathrm{SD}\end{array}$ & $47.6 \pm 12.3$ & $52.7 \pm 18.0$ & 0.037 \\
\hline $\begin{array}{l}\text { LDL-C }(\mathrm{mg} / \mathrm{dL}) \\
\text { mean } \pm \mathrm{SD}\end{array}$ & $121.8 \pm 36.2$ & $118.8 \pm 35.5$ & 0.57 \\
\hline $\begin{array}{c}\mathrm{FPG}(\mathrm{mg} / \mathrm{dL}) \\
\text { mean } \pm \mathrm{SD}\end{array}$ & $107.1 \pm 33.1$ & $109.0 \pm 41.5$ & 0.73 \\
\hline $\begin{array}{c}\text { Homocysteine } \\
(\mu \mathrm{mol} / \mathrm{mL}), \text { mean } \pm \mathrm{SD}\end{array}$ & $25.1 \pm 23.5$ & $13.0 \pm 5.3$ & $<0.001$ \\
\hline $\begin{array}{c}\text { Vitamin } \mathrm{B} 12(\mathrm{pg} / \mathrm{mL}) \\
\text { mean } \pm \mathrm{SD}\end{array}$ & $351.6 \pm 208.2$ & $463.0 \pm 280.3$ & 0.004 \\
\hline
\end{tabular}

a Two missing data; ${ }^{\mathrm{b}} 19$ missing data; ${ }^{\mathrm{c}} 20$ missing data; ${ }^{\mathrm{d}}$ six missing data in these variables. Abbreviations: BMI, body mass index; DBP, diastolic blood pressure; FPG, fasting plasma glucose; HDL-C, high-density lipoprotein cholesterol; LDL, low-density lipoprotein cholesterol; SBP, systolic blood pressure; TG, triglyceride; WC, waist circumference.

When we further explored the interaction effect between genetic variants of MTHFR and folate level status (low vs. normal) on metabolic parameters after adjusting for the effect of age, sex, duration of illness, and type of antipsychotics used, we found significant interaction effects between MTHFR A1298C and folate level status on body mass index (BMI) $(p=0.01)$ and waist circumference $(p=0.01)$, but not on other metabolic parameters. Specifically, patients with the MTHFR $1298 \mathrm{C}$ allele and low folate levels had significantly higher BMI and waist circumference (shown in Table 4). Regarding MTHFR C677T, the genotypes did not interact with the folate level status to influence metabolic parameters. 
Table 4. Interactions between MTHFR A1298C and folate levels in terms of body mass index and waist circumference in patients with schizophrenia.

\begin{tabular}{cllc}
\hline & MTHFR 1298AA & MTHFR 1298 AC + CC & $p^{\text {a }}$ \\
\hline $\begin{array}{c}\text { BMI }\left(\mathrm{kg} / \mathrm{m}^{2}\right), \\
\text { mean } \pm \text { SD }\end{array}$ & & & 0.01 \\
\hline Low folate level & $25.9 \pm 4.6(n=38)$ & $30.0 \pm 6.7(n=20)$ & \\
\hline Normal folate level & $26.4 \pm 5.0(n=97)$ & $26.1 \pm 5.0(n=56)$ & 0.01 \\
\hline WC $(\mathrm{cm})$, mean $\pm \mathrm{SD}$ & & & \\
\hline Low folate level & $89.4 \pm 10.9(n=38)$ & $98.7 \pm 12.4(n=20)$ & \\
\hline Normal folate level & $90.7 \pm 12.1(n=97)$ & $89.3 \pm 13.4(n=56)$ & \\
\hline
\end{tabular}

a Interactions between metabolic profiles and status of folate level on body mass index and waist circumference. Abbreviations: BMI, body mass index; MTHFR, methylenetetrahydrofolate reductase; WC, waist circumference.

No significant differences were noted in the distributions of genetic variants of MTHFR C677T and MTHFR A1298C, the folate level status, levels of folate, homocysteine, and vitamin B12, and type of antipsychotics used between patients with metabolic syndrome and those without metabolic syndrome (data not shown).

\section{Discussion}

To the best of our knowledge, this is the first study to investigate the effect of genetic variants of MTHFR and serum folate levels, as well as their interactions on metabolic parameters in patients with schizophrenia. Other than the finding that the MTHFR 677T allele was associated with lower levels of total cholesterol and LDL-C, we did not detect significant effects of MTHFR genotypes or the folate level status on metabolic parameters or metabolic syndrome in patients with schizophrenia. However, a significant interaction effect of MTHFR A1298C and the folate level status on BMI and waist circumference was noted.

Contrary to our hypothesis, patients with the MTHFR 677T allele had favorable metabolic parameters with significantly lower levels of total cholesterol and LDL-C in our study. In a similar attempt to examine the association between the genetic variants of MTHFR and metabolic parameters in patients with schizophrenia, two previous crosssectional studies on Caucasian patients failed to find any relationship between MTHFR C677T and metabolic parameters [16,22]. Ethnicity may be one of the reasons accounting for the differences between studies. Regarding the genetic effects of MTHFR polymorphisms on the vulnerability to metabolic syndrome or insulin resistance, existing research has reported inconclusive findings. MTHFR 677T carriers in Ellingrod's study [16] and MTHFR 1298C carriers in van Winkel's study [22] were reported to have higher risks of metabolic syndrome. Additionally, carriers with MTHFR 677T or MTHFR 1298C allele had a higher level of insulin resistance [23]. By contrast, the MTHFR 677T allele seemed to be protective against metabolic syndrome in Roffeei's study on Asian patients [17]. In our study, no relationship was found between MTHFR polymorphisms, whether MTHFR C677T or MTHFR A1298C, and metabolic syndrome. However, Srisawat et al. found that patients with MTHFR 677CC were associated with a greater increase in BMI compared with MTHFR 677T carriers in two cohorts of Chinese Han and Spanish Caucasians [24], both of which displayed similar minor allele frequency of MTHFR C677T and MTHFR A1298C. Taken together, these observations revealed inconclusive results in terms of the role of ethnic factor in the association between genetic variants of MTHFR and antipsychotic-induced body weight gain. Therefore, the effects of genetic variants of MTHFR on metabolic parameters should be further elucidated.

Notably, we found significant interactions between MTHFR A1298C and the folate level status in terms of BMI and waist circumference. Despite the current evidence that folate level is not significantly associated with metabolic syndrome [22] or antipsychoticinduced changes in metabolic parameters [25] in patients with schizophrenia, no study 
has investigated the possible interaction effect between genetic variants of MTHFR and folate levels on metabolic parameters. However, the interaction effect has previously been shown in nonpsychiatric patients. For example, MTHFR 677T carriers with a low folate level were associated with a higher risk of low HDL-C in Chinese patients with hypertension [26]. Similarly, a significant higher risk of coronary heart disease was noted in MTHFR 677T carriers, especially in those with low folate levels [14]. In addition to metabolic-related indices, the impact from interactions between genetic variants of onecarbon metabolism and folate levels on psychopathology in patients with schizophrenia has been reported [27]. Because the present study is the first to explore the interaction effect between genetic variants of MTHFR and folate levels on metabolic parameters in patients with schizophrenia, future studies with a larger sample size are warranted to verify our results.

Medications may affect the associations between genetic variants of MTHFR and metabolic parameters. Van Winkel et al. found that the effect of MTHFR A1298C on metabolic syndrome was greater in patients treated with clozapine or olanzapine [22]. However, we did not find any significant differences in metabolic parameters between patients with different genetic variants of MTHFR (either C677T or A1298C) in subgroups of patients receiving or not receiving clozapine/olanzapine treatment (data not shown).

The results of the associations between the genetic variants of MTHFR and metabolic parameters in patients with schizophrenia should be cautiously interpreted because they might be confounded by various factors such as the duration of illness and the medication effect from long-term antipsychotic exposure. Kao et al. found that the MTHFR 677C allele was significantly associated with antipsychotic-induced weight gain, but the effect seemed to be prominent in the subpopulation of first-episode patients [28]. Although one cross-sectional study revealed no association between the genetic variants of MTHFR and metabolic parameters in first-episode patients with schizophrenia taking short-term antipsychotics (mean, 6 days) [29], two longitudinal follow-up studies found that those with MTHFR 677CC gained more body weight or exhibited a more significant increase in BMI compared with MTHFR 677T carriers among first-episode patients with schizophrenia following antipsychotic treatment [24,25]. In addition, one recent study investigated the effect of MTHFR C677T on antipsychotic-induced changes of body weight gain and BMI, in which MTHFR 677C carriers had a higher body weight gain or BMI change than those with MTHFR 677TT in Chinese patients with schizophrenia [30]. The effects are different among antipsychotics used, especially in risperidone-treated patients, and more prominent in firstepisode patients with schizophrenia [30]. Therefore, MTHFR C677T may be significantly associated with antipsychotic-induced body weight changes, especially in the early stage of treatment.

Our study had several limitations. First, we recruited patients who were relatively chronic with a mean duration of illness of nearly 20 years. We did not collect information regarding lifestyle factors, such as diet and physical activities and antipsychotic use, which may confound our results. Second, we did not measure DNA methylation and S-adenosyl methionine (SAM), which is the methyl donor of DNA methylation, in the one-carbon cycle. Therefore, whether differences in DNA methylation and SAM exist between patients with different genetic variants of MTHFR or between patients with low folate levels and those with normal folate levels is unknown. Previous evidence has shown that MTHFR 677TT had the lowest DNA methylation compared with other genetic variants of MTHFR C677T in female patients with schizophrenia [31]. Global methylation increased, especially in patients treated with clozapine and olanzapine, and endothelial dysfunction improved after folate supplementation in schizophrenic patients with metabolic syndrome [32]. Certain regions of DNA methylation at birth were associated with obesity and insulin resistance in childhood [33]. In addition, site-specific DNA methylation has been shown to be associated with metabolic alternations in patients treated with antipsychotics [34,35]. Therefore, analysis of DNA methylation is essential when studying the associations between onecarbon metabolism and metabolic abnormalities. Third, the power to detect the effects 
of genetic variants of MTHFR on metabolic parameters was inadequate due to the small sample size. Fourth, we did not recruit healthy participants. Therefore, we could not determine whether there were any differences in the effects of MTHFR genetic variants on metabolic parameters between the general population and patients with schizophrenia.

\section{Conclusions}

Contrary to our hypothesis that patients with the minor allele of MTHFR (i.e., MTHFR 677T or MTHFR 1298C) and those with a low folate level may have worse metabolic parameters, we found that the MTHFR 677T allele was associated with lower levels of total cholesterol and LDL-C. No other significant effects of MTHFR genotypes or the folate level status on metabolic parameters or metabolic syndrome in patients with schizophrenia were noted. However, we found an interaction effect between the genetic variant and folate level on BMI and waist circumference. Genetic variants of one-carbon metabolism might play a role in antipsychotic-induced metabolic abnormalities, especially considering the effect of folate levels. Because of limitations in recruiting chronic patients, lack of a healthy control, and no DNA methylation data in the current study, prospective studies recruiting drug-naïve, first-episode patients with schizophrenia and healthy participants are needed in the future to identify changes in key regions of DNA methylation accounting for antipsychotic-induced metabolic abnormalities.

Author Contributions: C.-H.C., M.-L.L. and Y.-H.C., conceptualization, supervision, and validation; P.-Y.C. and C.Y.-A.C., methodology and data curation; C.-H.C. and Y.-K.L., methodology and formal analysis; C.-H.C., writing-original draft preparation; M.-C.H. and C.-C.C., writing-original draft preparation, review, and editing. All authors have read and agreed to the published version of the manuscript.

Funding: The study was supported by grants from the Ministry of Science and Technology, Taiwan (C.-H.C: 103-2320-B-038-022-MY3, 106-2314-B-038-051) and the Taipei Municipal Wan-Fang Hospital, Taipei Medical University, Taipei, Taiwan (C.-H.C: 103 TMU-WFH-11).

Institutional Review Board Statement: The study was conducted according to the guidelines of the Declaration of Helsinki, and approval was obtained from the Ethic Commission of Taipei Medical University and Taipei City Psychiatric Center. (Approval code: TMU-JIRB No 201408009).

Informed Consent Statement: Written informed consent was obtained from all participants before recruitment.

Data Availability Statement: The data presented in this study are available on request from the corresponding author.

Acknowledgments: The authors thank the recruited patients for their participation in this study. We also thank Yuan-Tung Chou for her assistance in recruiting patients and administrative affairs.

Conflicts of Interest: The authors declare no conflict of interest.

\section{References}

1. Newcomer, J.W. Antipsychotic medications: Metabolic and cardiovascular risk. J. Clin. Psychiatry 2007, 68 (Suppl. 4), 8-13. [PubMed]

2. Huang, M.-C.; Lu, M.-L.; Tsai, C.-J; Chen, P.-Y.; Chiu, C.-C.; Jian, D.-L.; Lin, K.-M.; Chen, C.-H. Prevalence of metabolic syndrome among patients with schizophrenia or schizoaffective disorder in Taiwan. Acta Psychiatr. Scand. 2009, 120, 274-280. [CrossRef] [PubMed]

3. Ryan, M.C.; Collins, P.; Thakore, J.H. Impaired Fasting Glucose Tolerance in First-Episode, Drug-Naive Patients with Schizophrenia. Am. J. Psychiatry 2003, 160, 284-289. [CrossRef] [PubMed]

4. Thakore, J.; Mann, J.; Vlahos, I.; Martin, A.; Reznek, R. Increased visceral fat distribution in drug-naive and drug-free patients with schizophrenia. Int. J. Obes. Relat. Metab. Disord. 2002, 26, 137-141. [CrossRef]

5. Lett, T.; Wallace, T.J.M.; Chowdhury, N.I.; Tiwari, A.K.; Kennedy, J.L.; Müller, D.J. Pharmacogenetics of antipsychotic-induced weight gain: Review and clinical implications. Mol. Psychiatry 2012, 17, 242-266. [CrossRef] [PubMed]

6. Grajales, D.; Ferreira, V.; Valverde, A.M. Second-Generation Antipsychotics and Dysregulation of Glucose Metabolism: Beyond Weight Gain. Cells 2019, 8, 1336. [CrossRef] 
7. Carl, G.F.; Crews, E.L.; Carmichael, S.M.; Benesh, F.C.; Smythies, J.R. Four enzymes of one-carbon metabolism in blood cells of schizophrenics. Biol. Psychiatry 1978, 13, 773-776.

8. Kelsoe, J.R., Jr.; Tolbert, L.C.; Crews, E.L.; Smythies, J.R. Kinetic evidence for decreased methionine adenosyltransferase activity in erythrocytes from schizophrenics. J. Neurosci. Res. 1982, 8, 99-103. [CrossRef]

9. Frosst, P.; Blom, H.; Milos, R.; Goyette, P.; Sheppard, C.; Matthews, R.; Boers, G.; den Heijer, M.; Kluijtmans, L.; van den Heuve, L.; et al. A candidate genetic risk factor for vascular disease: A common mutation in methylenetetrahydrofolate reductase. Nat. Genet. 1995, 10, 111-113. [CrossRef] [PubMed]

10. van der Put, N.M.; Gabreëls, F.; Stevens, E.M.; Smeitink, J.A.; Trijbels, F.J.; Eskes, T.K.; van den Heuvel, L.P.; Blom, H. A Second Common Mutation in the Methylenetetrahydrofolate Reductase Gene: An Additional Risk Factor for Neural-Tube Defects? Am. J. Hum. Genet. 1998, 62, 1044-1051. [CrossRef]

11. Castro, R.; Rivera, I.; Ravasco, P.; Camilo, M.E.; Jakobs, C.; Blom, H.; De Almeida, I.T. 5,10-methylenetetrahydrofolate reductase (MTHFR) 677C-> T and 1298A->C mutations are associated with DNA hypomethylation. J. Med. Genet. 2004, 41, 454-458. [CrossRef] [PubMed]

12. Friso, S.; Choi, S.-W.; Girelli, D.; Mason, J.B.; Dolnikowski, G.; Bagley, P.; Olivieri, O.; Jacques, P.F.; Rosenberg, I.H.; Corrocher, R.; et al. A common mutation in the 5,10-methylenetetrahydrofolate reductase gene affects genomic DNA methylation through an interaction with folate status. Proc. Natl. Acad. Sci. USA 2002, 99, 5606-5611. [CrossRef] [PubMed]

13. Luttmer, R.; Spijkerman, A.M.; Kok, R.M.; Jakobs, C.; Blom, H.J.; Serne, E.H.; Dekker, J.M.; Smulders, Y.M. Metabolic syndrome components are associated with DNA hypomethylation. Obes. Res. Clin. Pract. 2013, 7, e106-e115. [CrossRef] [PubMed]

14. Klerk, M.; Verhoef, P.; Clarke, R.; Blom, H.J.; Kok, F.J.; Schouten, E.G.; Group, M.S.C. MTHFR 677C $\rightarrow$ T polymorphism and risk of coronary heart disease: A meta-analysis. JAMA 2002, 288, 2023-2031. [CrossRef] [PubMed]

15. Mizuki, Y.; Sakamoto, S.; Okahisa, Y.; Yada, Y.; Hashimoto, N.; Takaki, M.; Yamada, N. Mechanisms Underlying the Comorbidity of Schizophrenia and Type 2 Diabetes Mellitus. Int. J. Neuropsychopharmacol. 2021, 24, 367-382. [CrossRef]

16. Ellingrod, V.L.; Miller, D.D.; Taylor, S.F.; Moline, J.; Holman, T.; Kerr, J. Metabolic syndrome and insulin resistance in schizophrenia patients receiving antipsychotics genotyped for the methylenetetrahydrofolate reductase (MTHFR) $677 \mathrm{C} / \mathrm{T}$ and $1298 \mathrm{~A} / \mathrm{C}$ variants. Schizophr. Res. 2008, 98, 47-54. [CrossRef] [PubMed]

17. Roffeei, S.N.; Mohamed, Z.; Reynolds, G.P.; Said, M.A.; Hatim, A.; Mohamed, E.H.M.; Aida, S.A.; Zainal, N.Z. Association of FTO, LEPR and MTHFR gene polymorphisms with metabolic syndrome in schizophrenia patients receiving antipsychotics. Pharmacogenomics 2014, 15, 477-485. [CrossRef]

18. Schneider, J.A.; Rees, D.C.; Liu, Y.-T.; Clegg, J.B. Worldwide Distribution of a Common Methylenetetrahydrofolate Reductase Mutation. Am. J. Hum. Genet. 1998, 62, 1258-1260. [CrossRef] [PubMed]

19. Clarke, R.; Bennett, D.A.; Parish, S.; Verhoef, P.; Dötsch-Klerk, M.; Lathrop, M.; Xu, P.; Nordestgaard, B.G.; Holm, H.; Hopewell, J.C.; et al. Homocysteine and Coronary Heart Disease: Meta-analysis of MTHFR Case-Control Studies, Avoiding Publication Bias. PLoS Med. 2012, 9, e1001177. [CrossRef]

20. Chen, K.-J.; Pan, W.-H.; Lin, Y.-C.; Lin, B.-F. Trends in folate status in the Taiwanese population aged 19 years and older from the Nutrition and Health Survey in Taiwan 1993-1996 to 2005-2008. Asia Pac. J. Clin. Nutr. 2011, 20, 275-282. [PubMed]

21. Alberti, K.; Eckel, R.H.; Grundy, S.M.; Zimmet, P.; Cleeman, J.I.; Donato, K.A.; Fruchart, J.-C.; James, W.P.T.; Loria, C.M.; Smith, S.C. Harmonizing the Metabolic Syndrome: A joint interim statement of the International Diabetes Federation Task Force on Epidemiology and Prevention; National Heart, Lung, and Blood Institute; American Heart Association; World Heart Federation; International Atherosclerosis Society; and International Association for the Study of Obesity. Circulation 2009, 120, 1640-1645. [CrossRef] [PubMed]

22. van Winkel, R.; Rutten, B.P.; Peerbooms, O.; Peuskens, J.; van Os, J.; De Hert, M. MTHFR and risk of metabolic syndrome in patients with schizophrenia. Schizophr. Res. 2010, 121, 193-198. [CrossRef]

23. Ward, K.M.; Burghardt, K.; Kraal, A.Z.; Jaeger, A.; Yeomans, L.; McHugh, C.; Karnovsky, A.; Stringer, K.A.; Ellingrod, V.L. Genetic and Metabolite Variability in One-Carbon Metabolism Applied to an Insulin Resistance Model in Patients with Schizophrenia Receiving Atypical Antipsychotics. Front. Psychiatry 2021, 12, 623143. [CrossRef] [PubMed]

24. Srisawat, U.; Reynolds, G.P.; Zhang, Z.J.; Zhang, X.R.; Arranz, B.; San, L.; Dalton, C.F. Methylenetetrahydrofolate reductase (MTHFR) 677C/T polymorphism is associated with antipsychotic-induced weight gain in first-episode schizophrenia. Int. J. Neuropsychopharmacol. 2014, 17, 485-490. [CrossRef] [PubMed]

25. Misiak, B.; Laczmanski, L.; Słoka, N.K.; Szmida, E.; Ślęzak, R.; Piotrowski, P.; Kiejna, A.; Frydecka, D. Genetic Variation in OneCarbon Metabolism and Changes in Metabolic Parameters in First-Episode Schizophrenia Patients. Int. J. Neuropsychopharmacol. 2017, 20, 207-212. [CrossRef]

26. Li, W.-X.; Lv, W.-W.; Dai, S.-X.; Pan, M.-L.; Huang, J.-F. Joint associations of folate, homocysteine and MTHFR, MTR and MTRR gene polymorphisms with dyslipidemia in a Chinese hypertensive population: A cross-sectional study. Lipids Health Dis. 2015, 14, 101. [CrossRef]

27. Roffman, J.L.; Brohawn, D.G.; Nitenson, A.Z.; Macklin, E.A.; Smoller, J.W.; Goff, D.C. Genetic Variation Throughout the Folate Metabolic Pathway Influences Negative Symptom Severity in Schizophrenia. Schizophr. Bull. 2013, 39, 330-338. [CrossRef] [PubMed] 
28. Kao, A.; Kuzman, M.R.; Tiwari, A.; Zivkovic, M.; Chowdhury, N.; Medved, V.; Kekin, I.; Zai, C.; Lieberman, J.; Meltzer, H.; et al. Methylenetetrahydrofolate reductase gene variants and antipsychotic-induced weight gain and metabolic disturbances. $J$. Psychiatry Res. 2014, 54, 36-42. [CrossRef] [PubMed]

29. Misiak, B.; Łaczmański, L.; Słoka, N.K.; Szmida, E.; Piotrowski, P.; Loska, O.; Ślęzak, R.; Kiejna, A.; Frydecka, D. Metabolic dysregulation in first-episode schizophrenia patients with respect to genetic variation in one-carbon metabolism. Psychiatry Res. 2016, 238, 60-67. [CrossRef] [PubMed]

30. Su, Y.; Yan, H.; Guo, L.; Lu, T.; Zhang, D.; Yue, W. Capoc Association of MTHFR C677T Polymorphism with Antipsychotic-Induced Change of Weight and Metabolism Index. Front. Psychiatry 2021, 12, 673715. [CrossRef] [PubMed]

31. Burghardt, K.J.; Pilsner, J.R.; Bly, M.J.; Ellingrod, V.L. DNA methylation in schizophrenia subjects: Gender and MTHFR 677C/T genotype differences. Epigenomics 2012, 4, 261-268. [CrossRef] [PubMed]

32. Ellingrod, V.L.; Grove, T.B.; Burghardt, K.J.; Taylor, S.F.; Dalack, G. The effect of folate supplementation and genotype on cardiovascular and epigenetic measures in schizophrenia subjects. NPJ Schizophr. 2015, 1, 15046. [CrossRef] [PubMed]

33. Van Dijk, S.J.; Peters, T.J.; Buckley, M.; Zhou, J.; Jones, P.A.; Gibson, R.A.; Makrides, M.; Muhlhausler, B.S.; Molloy, P.L. DNA methylation in blood from neonatal screening cards and the association with BMI and insulin sensitivity in early childhood. Int. J. Obes. 2018, 42, 28-35. [CrossRef]

34. Burghardt, K.J.; Goodrich, J.; Dolinoy, D.C.; Ellingrod, V.L. Gene-specific DNA methylation may mediate atypical antipsychoticinduced insulin resistance. Bipolar Disord. 2016, 18, 423-432. [CrossRef] [PubMed]

35. Delacrétaz, A.; Glatard, A.; Dubath, C.; Gholam-Rezaee, M.; Sanchez-Mut, J.V.; Gräff, J.; von Gunten, A.; Conus, P.; Eap, C.B. Psychotropic drug-induced genetic-epigenetic modulation of CRTC1 gene is associated with early weight gain in a prospective study of psychiatric patients. Clin. Epigenetics 2019, 11, 198. [CrossRef] [PubMed] 